http://e-journal.stit-islamic-village.ac.id/index.php/JM2PI

\title{
Implementasi Kedisiplinan dalam Peningkatan Prestasi Belajar Siswa di Mts Negeri 1 Kediri Jawa Timur
}

\author{
Nining Sulistiawati \\ Program Studi Pendidikan Agama Islam, STIT Islamic Village Tangerang \\ Email: Niningsulistia96@gmail.com
}

Received: September, 2020.

Accepted: Oktober, 2020.

Published: November, 2020

\begin{abstract}
The purpose of this study was carried out to find out how the application of student discipline in MTs Negeri 1 Kediri along with Supporting and inhibiting factors in the implementation of student discipline that had an influence on improving student learning achievement at MTs Negeri 1 Kediri Jawa Timur.

This study uses a qualitative approach in the form of field studies in MTs Negeri 1 Kediri. Data collection techniques in this study used observation, interviews, and documentation. Data analysis is done by collecting data, presenting data, reducing data, and verifying data or drawing conclusions. Test the validity of data by prioritizing data credibility, transferability, strength of reality, confirmation of research objects.

The results of this study indicate that in the implementation of discipline for students must be carried out by all elements of the school community and also connected with all school programs. The application of student discipline poses obstacles when the school discipline program is not carried out by all school members and is not supported by parents and student environment. Conversely students will be able to discipline if all school members carry out discipline and have the support of parents when students are at home. Disciplining students can improve student learning achievements both academic and non-academic.
\end{abstract}

Keywords: Discipline, Student Learning Achievement.

\section{ABSTRAK}

Tujuan penelitian ini dilaksanakan untuk mengetabui bagaimana penerapan kedisiplinan siswa di MTs Negeri 1 Kediri beserta dengan faktor pendukung dan penghambat dalam pelaksaan pendisiplinan siswa yang memberikan pengaruh terhadap peningkatan prestasi belajar siswa MTs Negeri 1 Kediri.

Penelitian ini menggunakan pendekatan kualitatif berupa studi lapangan di MTs Negeri 1 Kediri. Teknik pengumpulan data dalam penelitian ini menggunakan observasi, 
wawancara, dan dokumentasi. Analisis data dilakukan dengan cara pengumpulan data, penyajian data, reduksi data, dan verifikasi data atau penarikan kesimpulan. Teknik Uji validitas data dengan mengutamakan kredibilitas data, transferabilitas, kekuatan realitas, dan konfirmasi objek penelitian.

Hasil penelitian ini menunjukkan bahwa dalam pelaksanaan kedisiplinan bagi siswa harus dilakukan oleh semua elemen warga sekolah dan juga terkoneksi dengan seluruh program sekolah. Penerapan pendisiplinan siswa mendapatkan kendala ketika program disiplin sekolah tidak dilaksanakan oleh seluruh warga sekolah dan tidak didukung oleb orang tua dan lingkungan siswa. Sebaliknya siswa akan dapat disiplin apabila seluruh warga sekolah melaksanakan disiplin dan mendapat dukungan dari orang tua ketika siswa di rumah. Pendisiplinan terhadap siswa dapat meningkatkan prestasi belajar siswa baik prestasi akademik. maupun nonakademik.

Kata Kunci: Kedisiplinan, Prestasi Belajar Siswa.

\section{PENDAHULUAN}

Pendidikan merupakan salah satu unsur yang sangat penting untuk selalu dikembangkan dalam menunjang pembangunan nasional. Tidaklah berlebihan jika pemerintah selalu meningkatkan usaha perbaikan dan pengembangan dibidang pendidikan, baik formal maupun non formal. Hal itu semata untuk mencapai tujuan pendidikan nasional, seperti yang telah ditetapkan dalam UU NO. 20 Tahun 2003.

"Pendidikan nasional berfungsi mengembangkan kemampuan dan membentuk watak serta peradaban bangsa yang bermartabat dalam rangka mencerdaskan kehidupan bangsa, bertujuan untuk berkembangnya potensi peserta didik agar menjadi manusia yang beriman dan bertakwa kepada Tuhan Yang Maha Esa, berakhlak mulia, sehat, berilmu, cakap, kreatif, disiplin, mandiri, dan menjadi warga negara yang demokratis serta bertanggung jawab”.Elsam, (UU no 20 Tahun 2003 : 16). 
Dalam kaitannya dengan pendidikan nasional, seorang pendidik harus mampu mempertahankan nila-nilai positif dalam meningkatkan kedisiplinan serta akhlakul karimah siswa. Dari salah satu tujuan pendidikan yang tertera dalam UU No. 20 Tahun 2003 adalah menjadi manusia disiplin dan berakhlak mulia. Biasanya kedisiplinan siswa di sekolah dilihat berdasarkan kehadiran, waktu kedatangan ke sekolah, pengerjaan tugas, kegiatan belajar mengajar, dan mematuhi tata tertib sekolah. Sedangkan kedisiplinan siswa dirumah dilihat berdasarkan keteraturan dalam mengelola waktu dan kegiatan seperti, waktu belajar dan mengerjakan tugas sekolah dirumah. Orang yang disiplin akan tercermin mempunyai akhlak yang baik. Karena disiplin berarti patuh terhadap suatu peraturan yang sudah dibuat dan tidak menunda-nunda waktu.

Untuk menciptakan pendidikan yang optimal, diperlukan seorang pendidik yang berkompeten dibidangnya. Karena seorang pendidik akan dijadikan contoh untuk siswa dalam segala hal termasuk dalam menerapkan kedisiplinan baik di dalam ataupun di luar lingkungan sekolah. Apabila seorang pendidik tidak dapat menerapkan kedisiplinan baik di dalam maupun di luar lingkungan sekolah, akan memberikan dampak kepada peserta didik seperti kurangnya motivasi belajar dan suasana kegiatan pembelajaran menjadi kurang kondusif.

Motivasi belajar dan suasana pembelajaran yang kondusif akan membantu siswa untuk mencapai prestasi belajar baik akademik maupun non akademik. Untuk mencapai prestasi belajar peserta didik Hasbi Indra (2018:153) berpendapat:

"Dalam dunia pendidikan pada umumnya dikenal ada beberapa komponen pendidikan. Dalam konteks komponen pendidikan ini para ahli pendidikan memiliki pandangan yang berbeda. Misalnya, Soetari Imam Bernadib berpendapat bahwa, ada lima macam komponen pendidikan 
formal, yaitu tujuan, pendidik, anak didik, alat, dan lingkungan. Selanjutnya, Sudjana mengajukan pendapat bahwa komponen pendidikan ialah tujuan, pendidik, anak didik, materi pendidikan, metode, evaluasi, waktu penyelenggaraan, jenjang pendidikan, dan penyelenggaraan".

Berdasarkan pendapat di atas, komponen pendidikan bisa disimpulkan harus ada unsur; pendidik, peserta didik (siswa), lingkungan, metode, dan evaluasi. Jadi dari komponen tersebut pendidik (guru) sangatlah berperan penting dalam pendidikan. Sebagai pengatur sekaligus pelaku dalam proses belajar mengajar, guru berfungsi mengarahkan bagaimana proses belajar mengajar, dilaksanakan. Guru bukan hanya penyampai materi saja, tetapi lebih dari itu guru juga sebagai sentral dari pembelajaran. Karena itu guru harus membuat kondisi belajar yang efektif dan menarik dan membuat siswa senang dan merasa perlu untuk memperlajari hal yang disampaikan oleh guru tersebut. Mengingat guru mengemban tugas yang sangat berat untuk tercapainya tujuan pendidikan Nasional.

Oleh karenanya penerapan kedisiplinan di sekolah harus ditingkatkan kembali untuk dapat meningkatkan agar siswa dapat mencapai prestasi belajar. Banyak strategi pendisiplinan siswa yang dapat dilakukan pihak sekolah seperti pelarangan penggunaan alat komunikasi (Smartphone/gawai) ketika proses belajar mengajar di kelas berlangsung, sehingga kegiatan belajar mengajar bisa berjalan efektif.

Prestasi belajar merupakan hal yang penting dalam proses pembelajaraan, hasil belajar bisa diukur secara langsung dengan angka ataupun hasil belajar yang dapat dilihat dari pengaplikasian dalam kehidupan sehari-hari. Hasil belajar yang didapatkan oleh peserta didik yang berupa pujian maupun kritikan akan membuat peserta didik bisa mengevaluasi diri 
sendiri untuk lebih meningkatkan hasil belajar sehingga dapat memperoleh prestasi yang tinggi. Ma’sumah, (2015:6) Menyatakan:

"Prestasi merupakan hasil yang dicapai seseorang atau kelompok atas kegiatan yang telah dilakukannya. Tanpa sebuah kegiatan prestasi tidaklah dapat dicapai. Pada dasarnya, prestasi dan hasil belajar itu sama, artinya dalam prestasi belajar terdapat hasil belajar".

Selain peran seorang guru untuk meningkatkan prestasi belajar siswa, sekolah sebagai lingkungan pendidikan perlu menyediakan fasilitas belajar yang lengkap serta memadai. Sekolah harus mampu menciptakan budaya disiplin dengan menjalankan tata tertib oleh semua warga sekolah. Mengenai faktor yang memengaruhi kedisiplinan belajar siswa, dalam bukunya Ngalim Purwanto, Solihin, (2017:3) berpendapat faktor tersebut dapat di bedakan menjadi dua golongan yaitu: pertama, Faktor yang ada pada diri organisme itu sendiri, disebut faktor individual. Kedua, Faktor yang ada di luar individu, yang disebut faktor sosial.

Lingkungan sekolah menjadi faktor penting dalam meningkatkan kedisiplinan siswa sehingga memberikan pengaruh terhadap prestasi belajar siswa. Seperti di MTs Negeri 1 Kediri, berdasarkan pada pengamatan peneliti bahwa sekolah tesebut memiliki strategi sendiri dalam menciptakan kedisiplinan pada siswa-siswanya sehingga dapat menghasilkan prestasi bagi siwanya. Salah satu bentuk dari strategi yang ada di MTs Negeri 1 Kediri adalah pembudayaan disiplin baik bagi siswa, guru maupun karyawan sekolah tersebut.

\section{METODE}

Penelitian ini menggunakan pendekatan kualitatif berupa studi lapangan di MTs Negeri 1 Kediri. Teknik pengumpulan data dalam penelitian ini 
menggunakan observasi, wawancara, dan dokumentasi. Analisis data dilakukan dengan cara pengumpulan data, penyajian data, reduksi data, dan verifikasi data atau penarikan kesimpulan. Teknik Uji validitas data dengan mengutamakan kredibilitas data, transferabilitas, kekuatan realitas, dan konfirmasi objek penelitian.

\section{PEMBAHASAN}

\section{Penerapan kedisiplinan dan Analisanya}

Berdasarkan pada paparan data di atas bahwa penerapan kedisiplinan di MTs Negeri 1 Kediri didukung langsung oleh sekolah dalam penerapannya. Kedisiplinan telah diterapkan dengan baik dan benar sesuai dengan tata tertib yang ada disekolah, kedisiplinan tidak hanya berlaku bagi siswa, akan tetapi berlaku untuk semua warga sekolah tanpa terkecuali. Kedisiplinan diberlakukan bertujuan untuk bisa mewujudkan visi MTs Negeri 1 Kediri yaitu "Terwujudnya Insan Yang Religius, Unggul, Berprestasi dan Berwawasan Lingkungan”.

Hal ini sesuai dengan teori yang disampaikan oleh Merriam dari sisi sosiologi, disiplin merupakan serangkaian pola ketertiban yang bermanfaat untuk mengendalikan masyarakat dengan memberlakukan aturan-aturan juga sistem yang berlaku untuk semua orang (Aan Kurniawan Saputra, 2018:5). Disiplin yang diberlakukan terhadap tata tertib, diperuntukan untuk semua warga sekolah di MTs Negeri 1 kediri tanpa terkecuali. MTs Negeri 1 Kediri mengimplementasikan kedisiplinan dimulai ketika siswa masuk kesekolah sampai dengan selesai, yaitu mulai pada pukul 06.30 WIB sampai dengan $14.30 \mathrm{WIB}$. 
Penerapan kedisiplinan untuk siswa dimulai dari pengecekan atribut terlebih dahulu, kerapihan dalam berbusana, selanjutnya siswa menerapkan kegiatan 5S (Senyum, Sapa, Salam, Sopan, Santun), yang dilakukan setiap masuk ke area sekolah. Setelah itu siswa langsung masuk ke dalam kelas masing-masing untuk melakukan kegiatan bertadarus sebelum memulai kegiatan belajar mengajar.

Di sisi lain siswa yang terlambat kesekolah dengan berbagai macam alasan seperti bangun kesiangan, tidur terlalu malam, sekolah yang terlalu jauh, dan alasan lainnya, tidak boleh langsung masuk kedalam kelas. Siswa tersebut harus diberikan sanksi atau hukuman sesuai dengan alasan yang diberikan. Hukuman yang diberikan seperti membaca ayat pendek didalam Al-Qur'an, menulis istighfar sebanyak 100x, dan membersihkan lingkungan sekolah. Hukuman tersebut diberikan langsung oleh guru piket. Ketika selesai mengerjakan sanksi, maka siswa tersebut diberikan surat ijin masuk (SIM) kedalam kelas untuk mengikuti kegiatan belajar mengajar.

Untuk menerapkan kedisiplinan, sekolah didukung dengan adanya guru yang saling bekerja sama mendisiplinkan siswa setiap harinya, guru juga bertugas untuk memberikan arahan kepada siswa yang melanggar kedisiplinan, selanjutnya diberikan sanksi atau point yang disepakati pada surat pelanggaran, jika siswa mengulang kedisiplinan yang sama atau bahkan melanggar kedisiplinan yang lain sehingga poin kedisiplinan siswa bertambah banyak, maka siswa langsung diserahkan kepada Guru BK (Bimbingan Konseling) untuk di berikan bimbingan lebih lanjut.

Dalam proses pendisiplinan yang dilakukan di MTs Negeri 1 Kediri selaras dengan teori yang disampaikan Alex \& Manurung, (2019:83) mengenai teknik disiplin demokratis yakni: 
"Pendekatan disiplin demokratis dilakukan dengan memberi penjelasan, diskusi dan penalaran untuk membantu seseorang memahami mengapa diharapkan mematuhi dan mentaati peraturan yang ada. Teknik ini menekankan aspek edukatif bukan aspek hukuman. Sanksi atau hukuman dapat diberikan kepada yang menolak atau yang melanggar tata tertib. Hukuman dimaksud dengan tujuan meyadarkan, mengoreksi, dan mendidik".

Penerapan kedisiplinan di MTs Negeri 1 kediri juga diterapkan pada proses kegiatan belajar mengajar yang dilakukan oleh semua guru. Salah satunya Ibu Elvi Sayyidah, yang memulai pendisiplinan dalam kegiatan belajar mengajar dengan mematuhi tata tertib kelas yang sudah ada. Seperti pendisiplinan mengajak siswa berdo'a dan bertadarus terlebih dahulu sebelum memulai pembelajaran, merapihkan kondisi kelas dan kerapihan seragam siswa. Selain itu pendisiplinan dalam proses belajar mengajar juga di sampaikan oleh Ibu Asisul, jika pendisiplinan dilakukan oleh beliau dengan cara memberikan tanggung jawab kepada setiap individu. Siswa yang melakukan pelanggaran kedisiplinan seperti tidak mengerjakan tugas atau PR, membuang sampah di dalam kelas, atau terlihat berbicara bersama teman saat guru sedang menjelaskan materi didepan kelas. Maka siswa akan diberikan sanksi berupa teguran ringan, atau pemberian point terhadap siswa (W: Guru).

Segala bentuk pendisiplinan pasa saat kegiatan belajar mengajar di dalam kelas memiliki tujuan menjadika siswa terbiasa dan mampun mematuhi peraturan yang melekat pada diri siswa. Sehingga siswa tetap akan patuh dan taat aturan di luar sekolah dengan sudah terbiasanya disiplin taat aturan di sekolah. Sebagaimana dikatakan oleh James Drever bahwa disiplin merupakan kemampuan mengendalikan perilaku yang ada pada diri seseorang untuk mengikuti peraturan yang sudah diatur atau mengikuti norma yang sudah ada dan ditetapkan (Puspitasari, 2017:70). 
Dalam pendisiplinan pada kegiatan belajar mengajar juga di peruntukkan oleh guru, mengingat guru merupakan roel model siswa yang harus lebih disiplin. Namun dalam penerapan kedisiplinan didalam kelas masih ada salah seorang guru yang melakukan ketidakdisiplinan, seperti membawa hp didalam kelas, yang dikatakan siswa kelas 8B Nabila Aulia Ramadhani.

"Untuk kedisiplinan diterapkan kesemuanya, tapi kadang-kadang muridnya ada yang tidak disiplin, gurunya juga ada beberapa yang sembunyi-sembunyi bawa HP dikelas, Tapi siswa tidak berani menegor. Harusnya gak boleh, karena nanti siswa jadi ikut-ikutan bawa hp kedalam kelas" (W: Siswa)

Hal serupa juga disampaikan oleh Raditya Pranaja kelas 7K dalam sesi wawancara yang mengatakan jika ada salah seorang guru yang datang mengajar tidak tepat waktu. Hal ini sangat berdampak tidak baik bagi siswa, karena siswa bisa saja keluar masuk kelas jika tidak ada guru. Hal ini juga akan mengganggu kelas lain dalam kegiatan belajar mengajar. Sedangkan pendapat lain diberikan oleh siswa kelas 9J Fatimatuzahro yang membenarkan jika ada salah seorang guru yang membawa handphone dan memainkannya didalam kelas. Hal ini dirasa kurang pantas karena guru memainkan handphonenya didepan anak murid. Sedangkan tata tertib kelas sudah ada dimasing-masing kelas. Tidak baik jika seorang guru yang seharusnya memberikan contoh baik malah memberikan dampak negative atau bahkan mencontohkannya secara tidak sengaja. Hal ini sangat dikhawatirkan apabila siswa justru akan melakukan hal ketidakdisiplinannya karena contoh yang terlihat dari guru.

Seperti dalam teori Ekosiswoyo dalam jurnalnya (Hermiyanty, Wandira Ayu Bertin, 2017:47) dari segi etika Kedisiplinan merupakan sekumpulan perilaku individu ataupun masyarakat yang menunjukan perilaku taat, patuh, dan kesadaran dari diri masing-masing untuk melakukan kewajiban sebagai seorang yang bertanggung jawab dalam pencapaian tujuan. Seharusnya 
seorang guru mampu melakukan kewajibannya dalam memberikan contoh yang baik kepada muridnya dan bisa bertanggung jawab terhadap pelanggaran yang dilakukannya.

Sedangkan menurut pendapat siswa kelas 8C Reynalda Augustama yang mengatakan tujuan disiplin sendiri membuat orang menjadi tepat waktu dalam segala hal, tidak membuat orang lalai dengan janjinya. Menurut M. Assadulhaq kelas 9D mengatakan:

"Tujuan dari pada digalakkannya kedisiplinan tersebut adalah supaya menjadi orang-orang yang betul-betul disiplin, melatih diri kita menjadi orang yang konsisten". (W: Siswa)

Wali murid sendiri berpendapat jika disiplin bertujuan untuk menanamkan kehidupan yang lebih terarah untuk masa depan anak, seperti yang dikatakan oleh ibu Ibu Endang Pujiarti wali murid:

"Menurut saya disiplin itu sangat penting, harusnya malah dari usia dini anakanak harus diajarkan kedisiplinan untuk masa yang akan datang. Tujuan disiplin agar orang itu terarah, dan punya tujuan. karena dari disiplin mereka bisa mengatur waktu mereka, membagi bagi waktu mereka. Misalnya waktu belajar untuk belajar, waktu bermain untuk bermain, dan waktu tidur digunakan untuk tidur". (W: Wali)

Sedangkan menurut teori tujuan disiplin dari Yasin, (2011:128) adalah untuk : Membantu membentuk karakter siswa untuk menjadi pribadi yang bertanggung jawab, Membantu anak mengatasi dan mencegah timbulnya masalah disiplin dan menciptakan situasi yang baik bagi kegiatan belajar mengajar dimana mereka menaati peraturan yang ditetapkan.

Hasil analisa dari peneliti, kedisiplinan di MTs Negeri 1 Kediri sudah sangat bagus dalam penerapannya, di dukung dari pihak sekolah seperti guru dan para staffnya. Pendisiplinan ini tidak bisa berjalan tanpa adanya motivasi dan dukungan dari kedua orang tua, karena sebagian besar waktu dari siswa 
yaitu berada dilingkungan keluarga. Orang tua diharapkan dapat memberikan arahan dan dapat bekerja sama melatih siswa disiplin untuk menyeimbangkan peraturan disiplin siswa disekolah. Disiplin juga berlaku untuk guru tetapi dengan adanya salah seorang guru yang melakukan ketidakdisiplinannya, seperti pada wawancara siswa, dikhawatirkan akan menjadi contoh yang tidak baik untuk siswa, maka dari itu sebaiknya teguran atau sanksi yang diberikan kepada siswa juga diberlakukan untuk guru.agar siswa merasa adil, selain itu sebaiknya siswa diberi kebebasan dalam berdemokrasi, untuk memberi tahu guru lain atau pihak sekolah jika terjadi hal yang sama. Sehingga dapat di Analisa, bahwa kedisiplinan akan lebih optimal jika tata tertib lebih diketatkan lagi.

\section{Faktor penghambat dan pendukung dalam penerapan kedisiplinan}

Dalam penerapan kedisiplinan di MTs Negeri 1 Kediri tentunya ada faktor penghambat dan pendukung. Peneliti memulai menganalisa dari faktor penghambat terlebih dahulu. Dari hasil wawancara, observasi dan dokumentasi yang sudah didapat, peneliti mengkerucutkan bahwa faktor penghambat penerapan kedisiplinan lebih dominan pada lokasi tempat tinggal siswa yang rata-rata berada diluar daerah Pare-Kediri. Hal ini disampaikan melalui hasil wawancara bersama Kepala Sekolah, Ibu Rahayu Juwarini, Fatimatuzahro siswa kelas 9J, dan Wali murid, serta didukung dengan hasil Observasi dan dokumentasi kegiatan disekolah, yang melihat langsung jika memang benar banyak siswa yang menggunakan alat transportasi sepeda untuk bisa sampai kesekolah. Dan banyak dari mereka yang tempat tinggalnya berada diluar daerah, sehingga untuk sampai tepat waktu siswa harus berangkat pukul $05.00 \mathrm{WIB}$, namun jika ditengah perjalanan ada kendala seperti macet, ban bocor, atau hal lain maka siswa akan datang terlambat. Wawancara bersama Kepala sekolah :

JM2PI: Jurnal Mediakarya Mahasiswa Pendidikan Islam 
"Salah satu faktor penghambat ya karena biasanya transportasi yang digunakan itu umum, jadi mereka yang kurang beruntung gak kebagian tempat duduk terpaksa harus menunggu angkutan selanjutnya. Ada juga yang menggunakan sepeda, biasanya mereka lewat jalan raya yang banyak trek besar jadi mereka memilih aman untuk mengayuh sepedanya pelan”. (W: Kepsek)

Hal lainnya tidak semua siswa memiliki alat transportasi sepeda maka siswa menggunakan alat transportasi umum yaitu angkot. Untuk bisa sampai disekolah tepat waktu maka siswa harus ikut dengan angkot yang jalan dipagi hari, tak jarang jika angkot selalu penuh. Maka jika itu terjadi siswa harus menunggu angkutan berikutnya. Dan hal ini akan mengulur waktu siswa untuk sampai kesekolah dan siswa akan terlambat.

Faktor penghambat lain di sampaikan oleh siswa kelas 9D $\mathrm{M}$. Assadulhaq dan Lintang Nadief Narendra yang mengatakan jika faktor penghambat kedisiplinan berasal dari individu masing-masing. Bagaimana harus bisa mengatur waktu dengan baik, membagi waktu belajar dan bermain, ataupun menggunakan handphone dengan sewajarnya. Jika masing-masing individu bisa mengatur semua itu makan kedisiplinan akan bisa diterapkan:

"Sebenernya kalau kita disiplin waktu pasti gak ada faktor penghambat, tapi karena jam kita ini betul-betul pagi, jadi siwa jam istirahat nya kurang. Apalagi kalau mengerjakan PR terlalu malam, kadang membuat kita jadi bangun terlalu siang. Dan akhirnya belum menyiapkan peralatan sekolah. jadi terburu-buru kadang da nada yang ketinggalan". (W: Siswa)

Sesuai dengan teori yang disampaikan menurut Tu'u (Soewarno, Hasmiana, 2016:24) disiplin sangat diperlukan dalam mendidik anak supaya dengan mudah dapat menata kehidupan bersama. Disiplin berguna untuk menyadarkan seseorang bahwa dirinya harus menghargai orang lain dengan cara mematuhi peraturan dilingkungan yang ia datangi, sehingga tidak ada pihak yang dirugikan karena tidak adanya kedisiplinan. 
Sedangkan menurut pendapat dari Bapak Moh Kamim yaitu pengajar bimbingan konseling mengatakan jika salah satu faktor penghambat terjadi karena kedisiplinan disekolah yang kurang optimal. Menurut wali murid sendiri mengatakan jika faktor penghambat justru dari latar belakang siswa yang memang dari keluarga yang tidak mengedepankan kedisiplinan. Menurut beliau usaha untuk menerapkan kedisiplinan juga butuh didukung oleh keluarga:

"Faktor penghambatnya itu tadi, menertibkan anak itu sulit, dalam arti misal, kalo sekarang kita menjumpai anak yang memakai sepatu tidak hitam polos, kalau ditanya itu alasannya macam-macam, kemudian hari ini saya sita. Besoknya dipakai lagi dengan alasan tidak punya uang. Itu yang pertama". (W: Guru)

Hasil analisa dari peneliti sendiri jika faktor penghambat penerapan kedisiplinan di MTs Negeri 1 Kediri ada pada Jarak atau lokasi tempat tinggal siswa yang memang berada jauh dari sekolah. namun faktor penghambat ini bisa di minimalisir dengan cara menyadarkan individu siswa pentingnya kedisiplinan untuk bisa mnegatur waktu, sehingga tidak ada waktu yang terbuang. Hal lain yang bisa dilakukan yaitu dengan menegakkan kembali tata tertib yang sudah ada serta pihak sekolah harus menjalin komunikasi kembali dengan wali murid terkait cara bekerja sama untuk membentuk karakter siswa agar lebih disiplin.

Menurut hasil wawancara, observasi, dan dokumentasi yang sudah didapat jika faktor pendukung dalam penerapan kedisiplinan di MTs Negeri 1 Kediri yaitu dari pihak sekolah itu sendiri. Hal ini disampaikan oleh Ibu Juwarini, Ibu asisul guru Akidah Akhlak, Bpk Moh Kamim, Siswa kelas 7B khurin in, Siswa kelas 8B Nabila Aulia Ramadhani, dan diperkuat dengan hasil dokumentasi dan Observasi kegiatan sekolah. 
Pihak sekolah juga mendukung penerapan kedisiplinan di MTs Negeri 1 Kediri yaitu dengan adanya ektrakulikuler yang difasilitasi oleh sekolah. Dari beberapa ektrakurikuler yang ada menurut Nabila Aulia Ramadhani kelas 8B dan Via aprilian 8I yang sangat membantu dalam pendisiplinan di sekolah yaitu ekstrakulikuler PRAMUKA, OSIS, dan Jurnalis. Dilihat melalui dokumentasi foto yang mengabadikan lokasi kantor osis yang memiliki visi dan misi seorang pemimpin harus : "Jujur, Berani ,Tegas, Dapat di Percaya, Inisiatif, Bijaksana, Adil, Antusias, Setia, Mawadab". Hal ini Menambah nilai plus sendiri untuk siswa yang ingin meningkatkan kedisiplinan melalui ektrakulikuler OSIS.

Hal ini sesuai dengan teori yang disampaikan menurut Hergenhahn \& Olson (Yuzarion, 2017:109) dalam meningkatkan prestasi yaitu faktor sekolah. Sekolah sangat berperan besar dalam memberi pengaruh pada prestasi belajar siswa, jika sekolah bisa menciptakan suasana belajar yang kondusif.

Sebagai siswa di MTs Negeri 1 Kediri, Nabila Aulia ramadhani kelas 8B berpendapat jika faktor pendukung penerapan kedisiplinan yaitu dengan adanya ekstrakurikuler di sekolahnya, diantaranya OSIS, Pramuka, dan Jurnalis. Menurutnya pada ektrakulikuler yang disebutnya banyak menerapkan kedisiplinan. Misalnya dalam disiplin waktu, memiliki prinsip yang jelas, dan memiliki planning masa depan, hal itu bisa dimulai dari menerapkan kedisiplinan.

"Pendukung kedisiplinan disekolah yaitu ekstrakurikuler, seperti OSIS, Pramuka, jurnalis. Karena di OSIS diajarkan banyak prinsip komitmen dan kedisiplinan, dipramuka juga sangat disiplin waktu. Kalau dijurnalis saya diajarkan untuk mempunyai tujuan yang jelas. Jika ingin punya tujuan yang jelas siswa juga harus memiliki prinsip yang jelas". (W: Siswa) 
Selain pihak sekolah yang mendukung penerapan kedisiplinan menurut siswa M. Ardhenta Yurcel Alfarros kelas 9B menilai jika motivasi kedua orang tua sangat berpengaruh dalam menerapkan kedisiplinan. Terutama ketika siswa berada dilingkungan keluarga.

"Motivasi kedua orang tua sangat dibutuhkan Pendukungnya ya motivasi dari orang tua dan diri kita, agar menanamkan kedisiplinan sejak dini". (W: Siswa)

Selaras dengan pendapat dari siswa Ardhenta Yurcel Alfarros, orang tua juga berpengaruh banyak dalam mendukung kedisiplinan. Terutama ketika anak berada dilingkungan keluarga. Seperti teori disiplin secara eksternal yang disampaikan oleh Hergenhahn \& Olson (Yuzarion, 2017:109) Faktor lingkungan keluarga berpengaruh dalam penerapan kedisiplinan, dikarenakan sebagian waktu seorang siswa berada di rumah. Orang tua, dan adik kakak siswa adalah orang yang paling dekat dengan dirinya. Oleh karena itu, keluarga merupakan salah satu potensi yang besar dan positif memberi pengaruh pada prestasi siswa.

Selain motivasi dari kedua orang tua pendapat lain diberikan oleh Lintang Nadief Narendra kelas 9J yang mengatakan jika faktor pendukung kedisiplinan yaitu diri kita sendiri atau masing-masing individu (W:Siswa), Hal ini sama dengan teori yang di sampaikan oleh Damayanti, Anni \& Mugiarso, (2016:34-35) yang mengatakan jika faktor yang memengaruhi disiplin belajar siswa salah satunya dari faktor psikologis. Dikarenakan kondisi psikis individu yang baik akan memberikan pengaruh positif terhadap kegiatan belajar individu selama proses belajar berlangsung kondisi psikis manusia sangat mempengaruhi hasil belajar terutama motivasi. Motivasi memiliki peran penting dalam tercapainya disiplin belajar yang tinggi.

\section{Peningkatan prestasi belajar siswa dan Analisanya}


Dalam upaya meningkatkan prestasi belajar siswa, dibutuhkan kerja sama antara pihak sekolah terutama guru dan siswa. Selain itu juga dibutuhkan pendukung lain yang ada pada figure guru yaitu inovasi dan kreatifitas dalam upaya meningkatkan prestasi belajar siswa.

Inovasi dan kreatifitas guru diperlukan untuk mengembangkan sistem pembelajaran melalui metode yang menarik untuk diterapkan dalam kegiatan belajar mengajar, sehingga siswa tidak mudah bosan, dan dapat menerima materi melalui metode atau pembelajaran yang berbeda. Metode yang digunakan guru dapat disesuaikan dengan materi yang akan disampaikan. Misalnya materi pembelajaran disajikan dengan menggunakan audio visual dengan bentuk video, yang selanjutnya kemudian didiskusikan atau disimpulkan secara bersama-sama.

Keberadaan program-program sekolah dalam upaya meningkatkan prestasi belajar siswa, diberikan untuk menyalurkan bakat dan minat siswa, untuk lebih bersemangat lagi siswa di ikut sertakan dalam kegiatan lomba yang diadakan disetiap daerah baik program akademis maupun nonakademis . Sehingga siswa dapat melatih secara intens. Tidak hanya itu, dalam program ektrakurikuler yang ada siswa dilatih untuk lebih berdisiplin, kedisiplinan dilakukan pada kegiatan belajar mengajar ataupun pada kegiatan ektrakurikuler.

Dari analisa di atas, prestasi belajar siswa dapat ditingkatkan salah satunya dengan adanya guru yang memiliki inovasi dan kreatifitas, serta program sekolah yang dapat mendukung kegiatan siswa, selaras dengan hasil observasi peneliti yang dilakukan di MTs Negeri 1 Kediri, faktor yang dapat menunjang prestasi belajar siswa menurut Hergenhahn \& Olson (Yuzarion, 2017:109) diantaranya : 
1. Faktor sekolah, memiliki peran besar memberi pengaruh pada prestasi belajar siswa. bila sekolah berhasil menciptakan suasana kondusif bagi pembelajaran, hubungan dan komunikasi per orang di sekolah berjalan baik, metode pembelajaran aktif interaktif, sarana penunjang cukup memadai, siswa tertib disiplin. Maka kondisi kondusif tersebut mendorong siswa saling berkompetisi dalam pembelajaran. Keadaan ini diharapkan membuat hasil belajar siswa akan lebih tinggi.

2. Faktor pendekatan pembelajaran (approach to learning), yakni jenis upaya belajar peserta didik yang meliputi strategi dan metode yang digunakan peserta didik dalam mengikuti kegiatan pembelajaran.

Maka dari hasil penelitian yang dilakukan terdapat peningkatan prestasi belajar siswa MTS Negeri 1 Kediri setiap tahunnya. Capaian prestasi siswa tersebut diantaranya dari segi akademik nilai yang didapat siswa melampaui kriteria ketuntasan minimal mata pelajaran seperti pada mata pelajaran Aqidah Akhlak dan menjuarai berbagai kegiatan olimpiade mata pelajaran baik tingkat kabupaten kota, provinsi maupun nasional. Sementara itu dari segi prestasi non akademik diraih siswa diberbagai ajang dan cabang seperti keolahragaan, seni, dan lainnya. Prestasi yang didapat siswa tentunya banyak didukung oleh pendisiplinan dengan berbagai macan strateginya yang dilakukan oleh MTs Negeri 1 Kediri. Karena dengan berdisiplin akan membuat siswa menjadi dapat mengatur dengan baik waktunya untuk belajar dan berlatih. Berdasarkan hasil pemaparan data dan analisis yang telah dilakukan di atas peneliti mencoba menarik sebuah kesimpulan mengenai Implementasi Kedisiplinan Dalam Peningkatan Prestasi Belajar Siswa di MTs Negeri 1 Kediri Jawa Timur sebagai berikut : 


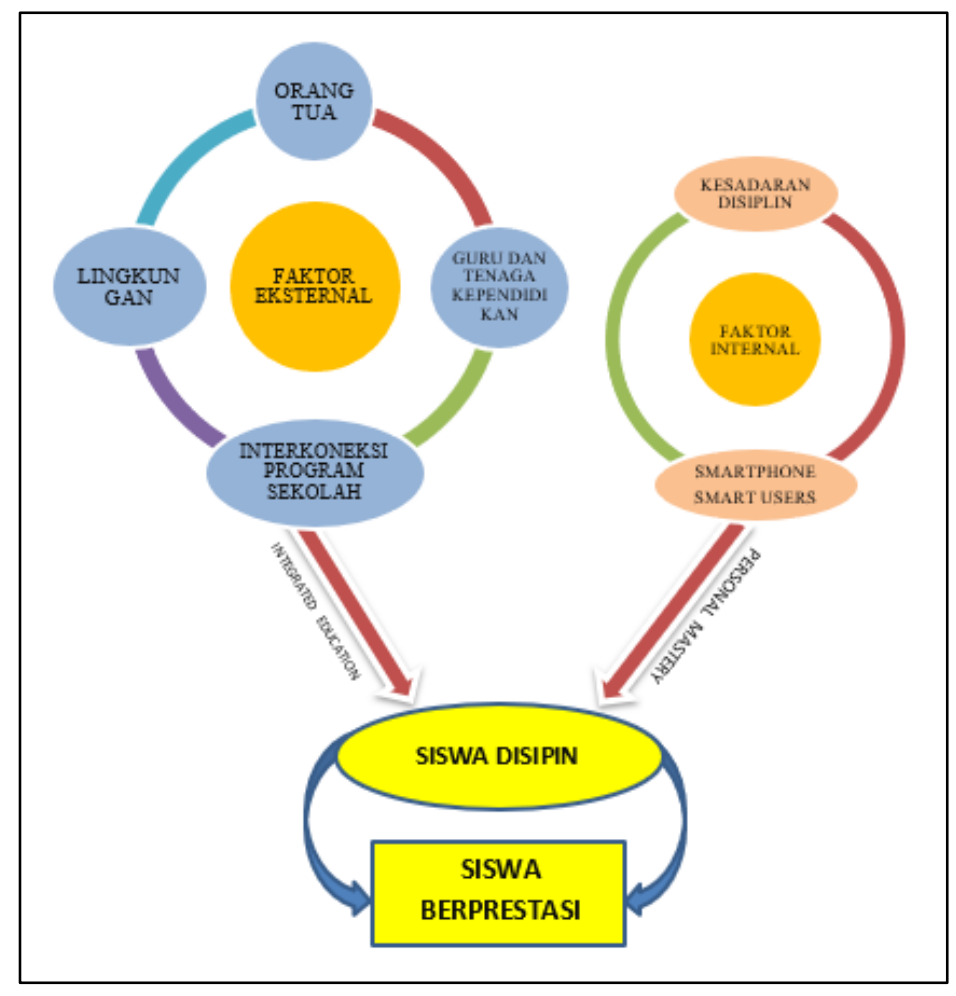

Gambar 4.2. Implementasi Kedisiplinan Dalam Peningkatan Prestasi Belajar Siswa di MTs Negeri 1 Kediri Jawa Timur

\section{SIMPULAN}

Berdasarkan hasil penelitian yang telah peneliti uraikan pada bab sebelumnya tentang "Implementasi Kedisiplinan Dalam Peningkatan Prestasi Belajar Siswa di MTS Negeri 1 Kediri Jawa Timur" dapat diperoleh kesimpulan bahwa implementasi kedisiplinan memiliki 2 faktor yaitu faktor ekternal yang meliputi orang tua, guru tenaga pendidik, lingkungan sekolah, dan interkoneksi program sekolah. Faktor Internal seperti kesadaran disiplin diri sendiri dan Smartphone smartuser. Bentuk Implementasi sekolah dalam menerapkan kedisiplinan untuk meningkatkan prestasi siswa diterapkan melalui praktek kehidupan disekolah setiap hari. Dimulai dari tata tertib yang 
ada yaitu datang tepat waktu, melaksanakan tugas piket kelas, berdo'a sebelum pelajaran dimulai, mendengarkan dan memperhatikan penjelasan dari guru, dilarang meninggalkan kelas pada saat jam pelajaran tanpa ijin guru, bersikap sopan, santun, dan menghargai semua warga sekolah, ikut menjaga 10K (Ketakwaan, Ketertiban, Keamanan, Kekeluargaan, Keindahan, Kebersihan, Kesehatan, Keterbukaan, Keteladanan, dan Kenyamanan), dilarang membawa HP (Hanphone). Implementasi kedisiplinan juga dilakukan langsung oleh para guru, dengan hadir tepat waktu saat mengajar, memakai pakaian rapih, serta menjaga ketertiban didalam kelas ketika kegiatan belajar mengajar. Sedangkan kedisiplinan untuk siswa diterapkan ketika siswa masuk dalam gerbang sekolah yang dimulai dari hadir tepat waktu, penggunaan atribut lengkap dan rapih dalam berpakaian. Tujuan disiplin sendiri untuk membentuk karakter siswa sejak dini sehingga lebih mudah diarahkan untuk menjadi seorang individu yang mempunyai prinsip dan pilihan dalam mewujudkan 1 visi sekolah yaitu "terwujudnya Insan Yang Religius, Unggul, Berprestasi dan Berwawasan Lingkungan". Faktor penghambat implementasi kedisiplinan disekolah yaitu karena faktor utama yaitu lokasi tempat tinggal siswa yang jauh dari sekolah, individual siswa yang kurang menyadari pentingnya kedisiplinan, tata tertib sekolah yang belum dilaksanakan secara optimal, latar belakang keluarga siswa yang jauh dari kata disiplin, dan lingkungan pergaulan siswa. Faktor yang pendukung implementasi kedisiplinan di MTs Negeri 1 Kediri yaitu dari pihak sekolah yang selalu mendukung penerapan atau kegiatan pendisiplinan siswa, motivasi kedua orang tua yang dibutuhkan siswa dalam menerapkan kedisiplinan disekolah dan dirumah, latar belakang sekolah yang sudah menjadi sekolah favorit, sehingga dalam memilih siswa sekolah sudah melakukan penyaringan atau seleksi, peran guru dalam mendukung implementasi kedisiplinan yang sangat berpengaruh apalagi seorang guru merupakan roel model siswa, dan Faktor 
pendukung lainnya yaitu Ektrakulikuler yang dinilai oleh siswa sangat membantu perilaku disiplin dalam program yang ada pada ektrakulikuler, terutama dalam program PRAMUKA, PMR, dan OSIS. Untuk menertibkan kedisiplinan sekolah memiliki poin pelanggaran yang sudah disepakati antara pihak sekolah, siswa dan wali murid. Poin pelanggaran tersebut memiliki 3 tingkatan yaitu : Pertama, kelompok ringan (A), sekolah memberikan poin 5 untuk pelanggaran yang dilakukan oleh siswa. Kedua, kelompok sedang (B), sekolah memberikan poin 10 untuk pelanggaran yang dilakukan oleh siswa. Ketiga, kelompok Berat (C), sekolah memberikan poin 30,50 dan 100. Dan tingkatan terberat yaitu pada poin 100, karena siswa diharuskan untuk Menulis surat pernyataan pengunduran diri dari madrasah. Peningkatan prestasi belajar siswa di MTs Negeri 1 Kediri bisa ditingkatkan melalui pembelajaran yang aktif dan interaktif melalui guru yang berinovasi, kreatif dalam melakukan kegiatan belajar mengajar. Serta adanya program sekolah yang terkoneksi dengan kedisiplinan seperti kegiatan ektrakulikuler yang memiliki program bersifat akademis maupun nonakademis untuk dapat menunjang prestasi belajar siswa baik di sekolah maupun diluar sekolah.

\section{REFERENSI}

Aan Kurniawan Saputra. (2018). Pengertian Disiplin.

Alex, S., \& Manurung, K. (2019). Hubungan Self Regulated Learning dan Disiplin Terhadap Prestasi Belajar. Pendidikan, 1-88.

Damayanti, M., Anni, C. T., \& Mugiarso, H. (2016). Persepsi Siswa tentang Faktor Yang Mempengaruhi Disiplin Belajar Pada Siswa XI. Pendidikan, 5(1), 39-44. Retrieved from journal.unnes.ac.id

Dr. Hasbi Indra, M. A. (2018). Pendidikan Pesantren dan Perkembangan SosialKemasyarakatan (Studi Atas (Cetakan pe; P. P. Dr. Hj. Imas kania Rahman, Ed.). Yogyakarta: CV Budi Utama.

Elsam. (2019). UU NO 20 TH 2003. Republik Indonesia. 
Hermiyanty, Wandira Ayu Bertin, D. S. (2017). HUBUNGAN KEDISIPLINAN TERHADAP HASIL BELAJAR SISWA KELAS V DI SD NEGERI 10 BANDA ACEH. Journal of Chemical Information and Modeling, 8(9), 1-58. https://doi.org/10.1017/CBO9781107415324.004

Ma'sumah, S. (2015). Pengaruh Disiplin Belajar terhadap Prestasi Belajar Siswa Kelas IV Sekolah Dasar Negeri Se-Daerah Binaan II Kecamatan Pertahanan Kabupaten Kebumen. Universitas negeri Semarang.

Soewarno, Hasmiana, F. (2016). Prodi Pendidikan Guru Sekolah Dasar Fakultas Ilmu Pendidikan Unsyiah Banda Aceh. Jurnal Ilmiah Mahasiswa Prodi PGSD FKIP Unsyiah, 1(1), 21-30.

Solihin. (2017). Pengaruh Kedisiplinan Terhadap Prestasi Siswa Sman 1 Benai Kabupaten Kuantang Singinggi (Study Kasus Kelas IX). 4(1), 1-15.

Yasin, F. (2011). Penumbuhan Kedisiplinan Sebagai Pembentukan Karakter Peserta Didik Di Madrasah. El-Hikmah, 0(1), 123-138.

Yuzarion. (2017). Faktor yang mempengarubi prestasi belajar peserta didik. 107-117. 